\title{
AN EXAMINATION OF THE VARIABLES INFLUENCING THE FUEL RETAIL INDUSTRY
}

\author{
K.Sartorius, C Eitzen \& J Hart, University of the Witwatersrand, Johannesburg, South Africa
}

Purpose/objectives: The objective of the study is to contribute to a better understanding of the key variables that influence the profitability of this sector, as well as to develop a reliable model to predict retail fuel sales volumes in an urban setting.

Problem investigated: South African fuel retail outlets are confronted by a wide range of variables that constrain profit and a significant number of outlets are not profitable. In the event of further deregulation, it is conceivable that many fuel stations will go out of business.

Methodology: A combination of a quantitative and a case study methodology, in conjunction with a literature review, was used to test the principal research questions.

Findings/implications: The results suggest that location significantly influences urban retail fuel sales volumes whilst fuel station size and the fuel price play a lesser role. Other significant factors, however, also influence fuel station profitability. The demand for petrol appears to be relatively inelastic in the short term and more elastic over the long term. Conversely, the demand for diesel appears to be completely inelastic.

Value: The article promotes a better understanding of the cost dynamics of the fuel industry. In this regard, the model constructed to predict urban fuel station turnover indicated high levels of reliability. Furthermore, few comparable studies have been published in accounting journals.

Conclusion: The study concludes that urban petrol stations selling more than 370000 liters of fuel per month are likely to be profitable and that location is a key variable influencing sales. In the event of deregulation, many operators are likely to be eliminated because of high levels of competition and low profit margins. An even greater number of fuel stations, therefore, will be reliant on non forecourt activities to survive.

Key words and phrases: Fuel retail outlet, variable, deregulation, price elasticity

\section{INTRODUCTION}

The South African retail fuel industry is a highly sophisticated industry built on a solid infrastructure (Human Sciences Research Council, 1992). In this regard, refineries import crude oil from three main sources, namely: Saudi Arabia; Iran; and Nigeria (Mbendi, 2004b). South Africa has the second largest refining capacity in Africa and processes approximately 20 million tons of crude oil per annum, as well as owning one of the world's largest coal-to-motor fuels plants (Sasol), which supplies $44 \%$ of its fuel demand (Cohen, 2005). In total, the refineries, the Sasol plant, and the Mossgas plant, have a combined daily capacity of 708000 barrels of crude oil (Bain, 2005). Currently, consumers demand approximately 23 million tons of liquid fuel products per annum (Mbendi, 2005a) which are sold to the public by 4500-5000 fuel retail service stations. Approximately $90 \%$ of fuel stations are supplied by one of the larger oil companies which include Engen, Shell, Caltex, BP, Total and Sasol at a price fixed by the Department of Minerals and Energy (Human Sciences Research Council, 1992; Thomas, 2005 and Mbendi, 2004b).

The fuel retail sector operates in a highly competitive environment that is characterised by low profit margins and high stock turnover. It is both capital and labor intensive, with approximately 58000 pump attendants employed in the sector (Thomas, 2005). A study conducted by the DME in 2004, found that the average fuel station sold 270000 liters of fuel per month, with approximately $70 \%$ of all fuel stations selling only 200000 liters (Thomas, 2005). Despite the regulation in the industry, the DME found that only $40 \%$ of fuel stations are profitable with regard to selling fuel. Many fuel stations have explored alternative sources of income in order to remain profitable and there is a concern that there are too many fuel stations, resulting in an overtraded market (Thomas, 2005). According to the DME, the retail market may be overtraded by as much as 30\% (Visser, 2005). 
The reliance of fuel stations on additional sources of income is commonplace in de-regulated markets. In the USA, fuel is considered the volume driver, whilst convenience store sales drive the bulk of the profits (Reid, 2004). A survey performed by National Petroleum News in 2005, indicated that $66.5 \%$ of sales relate to motor fuel, but these sales only contributed $31.7 \%$ to the gross profit in the industry. Therefore $68.3 \%$ of the gross profit in the US fuel retail industry is derived from convenience store sales. The United Kingdom is no different, and Shell has admitted that they make no profit from UK fuel sales (Harwood, 2006). Profits from European fuel sales are also being eroded, causing companies to search for new revenue streams (Weirauch, 2000). South African fuel retailers are already relying heavily on convenience store sales, in an overtraded industry, to remain profitable. With the impending deregulation of the industry, it is imperative that retailers understand the variables affecting the profitability of outlets in order to remain in the industry.

Deregulation of the South African fuel retail industry is expected to cause a variety of changes to the sector. These changes will include the deregulation of the fuel price and import and export controls would be phased out, allowing companies to import and refine crude oil or to import the finished fuel (Mbendi, 2005d). Deregulation is likely to have extensive effects on the overtraded fuel retail market. Lower pump prices, caused by additional competition, will result in lower profit margins being earned by fuel stations (Visser, 2005). The Human Sciences Research Council foresees deregulation having extensive consequences for existing fuel stations, with the likely demise of marginal outlets and the reduction in the number of low volume rural outlets (Human Sciences Research Council, 1992). The Financial Mail predicts that approximately 1600 of the current 4800 fuel stations could close once the market is liberalised (Pile 2005). A side effect of the termination of these fuel stations is the major job losses that would result (Mbendi, 2005c).

The objective of this study is to contribute to a better understanding of the key variables that influence the profitability of urban retail fuel station outlets. Sales volume of petrol has been used as a proxy for the profitability of retail fuel stations due to the confidential nature of profit data. This proxy is considered appropriate as profitability is normally a direct function of fuel sales volume (Smalley, 1999). Furthermore, as fuel sales increase, there is a greater likelihood of customers utilising non forecourt facilities like convenience stores, car washes and ATMs (Smalley, 1999). The first research question is what key variables influence sales volume of fuel? In this regard, the following three hypotheses are tested.

- $\mathrm{H}_{1}$ : Sales Volume $=f$ (Location)

- $\mathrm{H}_{2}$ : Sales Volume $=f$ [Size of the Fuel Station (number of pumping bays)]

- $\mathrm{H}_{3}$ : Sales Volume $=f$ (Fuel Price)

The second research question tests whether variables other than location, size and the fuel price influence profitability. The study only investigates the factors that influence retail fuel station profitability in an urban setting and ignores both rural areas, as well as fuel stations alongside national highways.

The welfare of the South African fuel retail industry is an important sector of the South African economy because of its contribution to the gross domestic product, as well as the fact that this sector employs over 58000 workers (Thomas, 2005). Further deregulation of the industry could result in lower margins that precipitate job losses and the closure of marginal fuel stations (Visser, 2005). Given the importance of this sector, it is an urgent priority to better understand the variables that influence the viability of these fuel stations. In particular, the study will contribute a management accounting perspective to identifying and quantifying (where possible) the variables that influence profitability.

The outline of the remainder of the paper is as follows: Section 2 discusses variables that influence the profitability of the retail fuel sector; Section 3 outlines the methodology and data; Section 4 develops the results; Section 5 discusses the results; and, finally, Section 6 reaches a conclusion and makes recommendations for future areas of research. 


\section{THE FUEL RETAIL INDUSTRY}

There are approximately 4800 fuel retail stations within South Africa (Thomas, 2005). Approximately half of these are owned and managed by independent dealers while the other half are owned by oil companies and leased out to dealers (Human Sciences Research Council, 1992). The activities of service stations can be separated into two categories. Firstly, forecourt activities include the sale of petrol, diesel, illuminating paraffin, liquid petroleum gas and lubricants. Secondly, additional activities could include convenience stores, car washes, ATMs and public telephones. In South Africa, the pricing of certain fuels is regulated. This includes the retail price of petrol and the wholesale price of diesel, kerosene and illuminating paraffin. Petrol may not be sold on credit, nor may it be sold at a discount and access to new entrants in the retail fuel sector is restricted. On the other hand, diesel has essentially been deregulated with respect to the retail industry for the past few years (Human Sciences Research Council, 1992 and Mbendi, 2004b; 2005b). Finally, selfservice at fuel stations is prohibited in order to protect jobs (Human Sciences Research Council, 1992).

The profitability of fuel retail stations has been declining. The cost of a new fuel station, often financed by one of the supplier-oil companies, ranges from R10 to R30 million (Thomas, 2005). In addition, operating costs are high and $50.83 \%$ of gross profit includes the remuneration of pump attendants, cashiers, administrative staff and the owner's salary or return on investment. Other expenses are rental (15.64\% of gross profit) and interest costs $(2.11 \%$ of gross profit) which are incurred for holding stock (fuel retailers are required to pay for all stock upfront). In addition, own advertising costs make-up $0.50 \%$ of gross profit. Supplier oil companies incur the majority of advertising expenses which are recouped through the marketing margin. Other significant expenses (22.69\% of gross profit) include bank charges, water and electricity, telephone, and infrastructure maintenance (SBAB, 2004). According to the 2004 SBAB report, total costs made up $91.77 \%$ of gross profit leaving $8.33 \%$ net profit before tax (SBAB, 2004). However, in practice, many fuel stations earn a return on assets of below 7\% (Human Sciences Research Council, 1992 and FleetCube, 2005). In this regard, the profitability of the retail fuel sector appears to be significantly influenced by the dealer margin, the location and size of the service station, and the price elasticity of demand.

\section{The Dealer Margin}

The retail fuel price of petrol that is charged to the consumer, as illustrated in Figure 1, is based on the Basic Fuel Price (BFP) Formula and is made up as follows: $50 \%$ is allocated to the basic fuel price; $31 \%$ is allocated to government in the form of fuel taxes and levies; and a further $11 \%$ is allocated to wholesale oil companies; leaving $8 \%$ for the fuel stations. The basic fuel price as determined by the BFP formula is calculated using $50 \%$ of the spot price quoted in the Mediterranean and $50 \%$ of the spot price quoted in Singapore (Mbendi, 2004a). Additional shipping and importing costs are added to the basic fuel price which is first calculated in US dollars before being converted into South African Rands (Mbendi, 2004b). Finally, taxes and allocations to oil companies and fuel retail stations are added to the adjusted basic price in order to calculate the retail fuel price.

The $8 \%$ allocation to fuel retail stations is essentially the contribution margin made by these stations. In order to illustrate this margin, as at 29 December 2005, the retail dealer margin was 43.6 cents per liter of petrol (Department of Minerals and Energy, 2005b). This margin is determined by the DME on the basis of the actual distribution costs incurred by fuel stations. An annual survey of 100 fuel stations is used as the basis to determine the average income and costs of the fuel retail sector. The retail dealer margin is then calculated based on a $20 \%$ mark-up on the average operating expenses of the 100 fuel stations in the survey (The Department of Minerals and Energy, 2005a).

Similarly for diesel, $59 \%$ of the diesel wholesale price is allocated to the basic fuel price, $29.5 \%$ to the government and $12.5 \%$ to wholesale oil companies. The retail price of diesel is not regulated, leaving the fuel station to decide on a price per liter to sell to the public. However, the wholesale price of diesel is regulated. Therefore, the price at which fuel stations buy diesel is fixed by the DME. 


\section{Figure 1: Petrol and diesel price make-up}

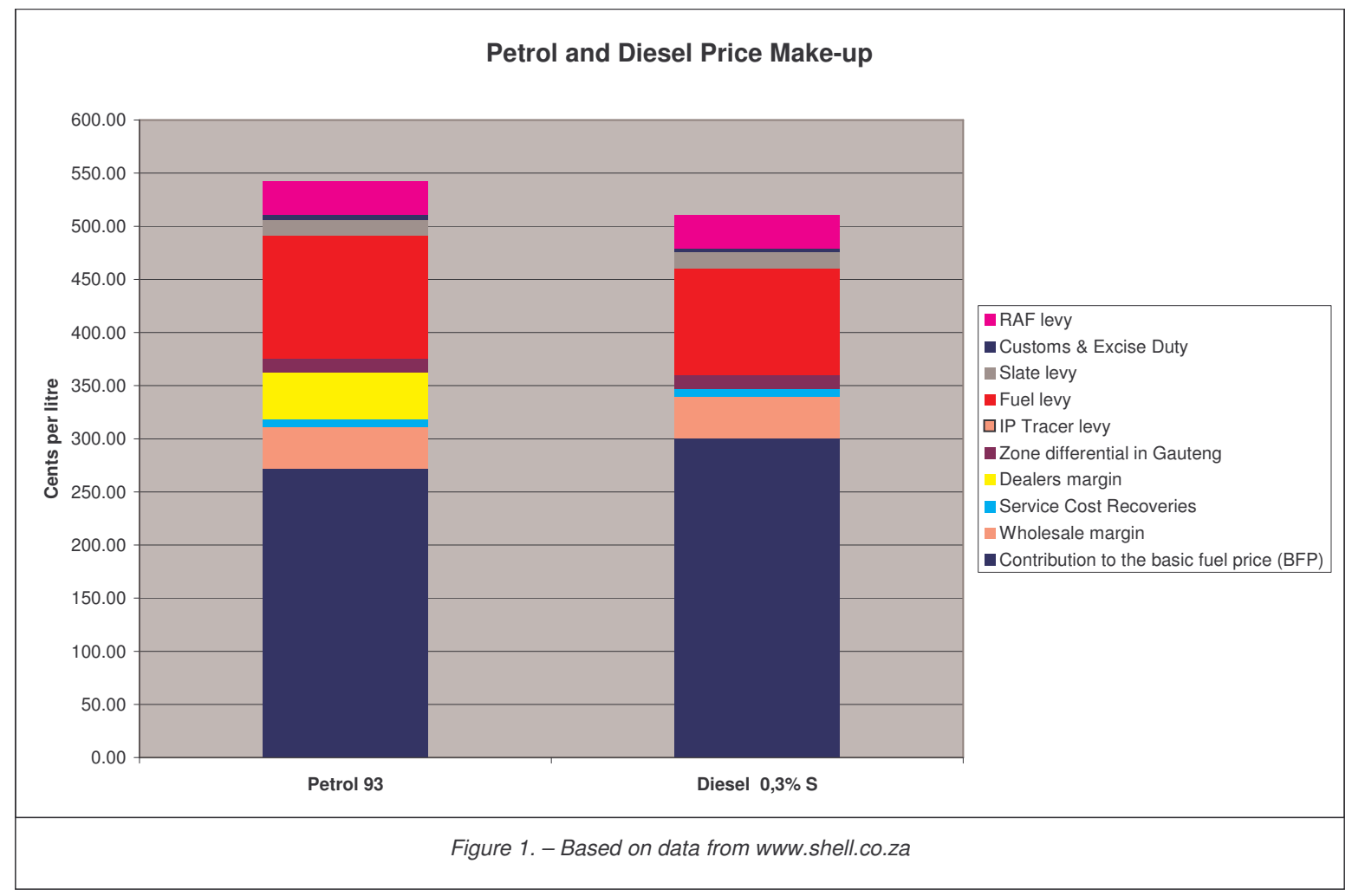

\section{Location}

The location of any retail business is an important factor affecting the performance and success of that business (Chan, Padmanabhan \& Seetharaman, 2005). Location may be important in relation to fuel retail stations if there is a correlation between the location of fuel stations and the demand for fuel. According to Chan et al. (2005), the demand for petrol can be expressly linked to local geographical and demographic factors such as; population, median income, number of cars, proximity to airport, downtown and highways. Therefore, the location of a fuel retail station in a rural area, for example, should influence a lower demand for petrol than an urban area due to a lower population, lower median income, fewer cars, and poorer proximity to an airport. In this regard, PTT Oil of Thailand indicated that it would close 300 petrol stations in unprofitable locations in rural areas. A long distance between fuel service stations, however, increases the volume of petrol and diesel sold (Hillingdon Times, 2006). In this regard, a review of rural petrol stations in Scotland indicated that, to be viable, these stations should be more than 8 miles to the next petrol station or more than 30 minutes drive from the edge of a town with a population of 30000 or more (Scottish Executive Publications, 2006 and Siam Future Development PLC, 2006). Another important location factor that could affect fuel demand is the accessibility of the site to customers (Lee \& Schmidt, 1980). Street intersection sites and corner sites are preferred locations as they offer better access, improved visibility and higher traffic volume (Lee \& Schmidt, 1980) and a signalised intersection improves access into and out of the fuel station (Smalley, 1999). Finally, customers prefer fuel retail stations that are close to work and home and convenience and accessibility to enter and exit is becoming increasingly important (Blum, Foos \& Guadry, 1988; Smalley, 1999; Bainbridge, 2000 and Chan et al., 2005).

The proximity of a fuel retail station to major routes may also be an important driver of fuel demand (Netz \& Taylor, 2002). In this regard, customers attempt to reduce travel time and distance when commuting or traveling longer distances and, therefore, select fuel retail stations which are in close proximity to these routes (Chan et al., 2005). This should be especially valid in South Africa where there is no price differentiation and, therefore, no incentive to travel any further than necessary. Therefore, fuel retail stations located near major routes and highways on route to work or home are 
more exposed to passing traffic and should have a higher demand for fuel then fuel retail stations located in residential areas (Netz \& Taylor, 2002 and Bainbridge, 2000).

\section{Size of Petrol Station}

The size of the petrol station and the number of pumping bays available is an indication of the convenience of filling at a particular station (Smalley, 1999). Customer convenience is an important variable that has a significant influence on sales volume. Although there a many variables influencing customer convenience, one important factor is the number of pumps that can refuel cars. This provides an indication of the number of cars that can refuel without negatively affecting the traffic flow on the site or delay the refueling time. Customers do no like to wait to refuel and tend to avoid stations where back up problems exist (Smalley, 1999). The number of pumping bays may provide a good indicator of the number of cars that can refuel without causing back up problems and provide an indicator of the volume of petrol that may be sold. Chan et al., (2005) also confirmed that station characteristics such as the number of pumping bays affects the market share of a particular fuel station and, therefore, the fuel demanded by customers.

\section{Price Elasticity of Demand}

The price elasticity of demand is defined as "the percentage change in the quantity demanded divided by the corresponding percentage change in its price" (Begg, 2000). The application of this theory to the retail fuel industry proposes that an increase in the fuel price leads to a reduction in the demand for fuel. Considerable research has attempted to identify factors that influence fuel demand, as well as provide insights into the sensitivity of consumer demand to fuel prices changes (Espey, 1996). Fuel price has been identified as one of the key variables affecting the demand of fuel (Graham \& Glaister, 2002), however, South African consumers have indicated a relatively inelastic short term demand for fuel because of a lack of alternative transport systems. It could be expected, however, that higher levels of elasticity could be achieved through a combination of a reduction in the use of vehicles, lift-clubs, the use of public transport, better driving techniques, more regular servicing of vehicles and a shift to more fuel efficient vehicles in the longer-term (TDM Encyclopedia, 2005a; 2005b). In this regard, Graham and Glaister (2002) also highlighted the impact of a better infrastructure and a functional public transport system on fuel demand.

Graham and Glaister (2002) performed an extensive international survey on the response of motorists to fuel price changes that indicated a fairly narrow range for short term price elasticity and a bigger range for long term price elasticity. This research concluded that, in general, international short-term price elasticity ranged between -0.10 and -0.3 and long-term price elasticity between -0.6 and -0.8 . The price elasticity of gasoline in the USA, for instance, was estimated to be -0.15 in the short run and -0.6 in the long run (Bailly, 1999). In South Africa, the Bureau for Economic Research (2003) estimated that the short and long term price elasticity of demand for petrol ranged between -0.21 and -0.51 respectively. All of these results indicate short term inelastic conditions that become more responsive over time. In this regard, short term inelasticity with respect to petrol in South Africa is illustrated by a $17 \%$ increase in the petrol price in 2005 which only resulted in a $0.2 \%$ drop in sales of R12 billion (Mbendi, 2005f). With respect to diesel, an even more inelastic situation prevails in South Africa and the Bureau for Economic Research (2003) estimated the price elasticity of demand for diesel ranged between -0.06 and -0.18 for both long and short term respectively in 2003.

\section{Other Variables}

Customers often buy more than just fuel when visiting a fuel retail station (Netz \& Taylor, 2002) and customer convenience appears to be driving the industry (Bainbridge, 2000). In this regard, fuel retail stations are increasingly differentiating themselves through the additional services that are offered and the presence of convenience stores, car wash facilities and specialty stores increase the market share of a fuel station (Chan et al., 2005). General cleanliness and appearance, as well as the quality and speed of service, are other factors that improve the customers' experience and increase repeat customers. These variables are even more important within a South African context where price is regulated and fuel stations need to differentiate themselves by a means other than fuel price in order to maintain and increase market share. In America, visionary companies are 
turning fuel retail stations into more convenient transitory stops or even final destinations by providing a variety of services through a 'village hub' type service station (Weirauch, 2000).

\section{METHODOLOGY}

A dual quantitative and qualitative methodology was employed to test the two research questions. Regression analysis was used to test the first research question because of the quantitative nature of the data. Conversely, a longitudinal case study methodology was used to test the second research question in order to explore a wider range of variables influencing the profitability of the retail fuel sector.

\section{The First Research Question - A Survey}

A survey of a selection of fuel stations in the Gauteng area was conducted (see Appendix B). The sample size included 31 fuel stations for 2005 and 29 fuel stations for 2004, representing approximately $2 \%$ of the fuel stations in Gauteng. The data included the average monthly sales volume in liters (the dependent variable- a proxy for profit), as well as details of the predictor variables influencing sales volume, namely: location; the number of pumping bays (a proxy for size); and the petrol price. The reason for using sales volume as a proxy for profit was because fuel station owners were reluctant to reveal details of their profit. Scattergrams and descriptive analysis were used to illustrate these relationships. Univariate, as well as multivariate regression analysis was then employed to determine the relationships between the variables. The study employed Stata (Version 9) to run the regression models and evaluate the residual diagnostics including the analysis of unusual and influential data, checking normality and homoscedascity, checking linearity and finally, verifying the model specification. The final suggested model also involved the transformation of the independent variable. The data specifically excluded fuel stations on national highways. The three hypotheses tested are as follows:

\section{$H_{1}$ : Sales Volume $=f$ (Location)}

In order to quantify the independent variable, a rating between 1 and 10 ( 1 being poor and 10 being excellent) was used. The rating was broken-down into four components that included location in relation to a major route (3 points), access to the fuel station ( 3 points), geographical location that was based on proximity to rural/urban area ( 3 points) and an extra point for location near a major shopping centre. The dependent variable, namely, sales volume, used the average monthly sales volume in liters. Univariate regression analysis was employed to determine the significance of the relationship between the location rating $(1-10)$ and the annual sales volume in liters for the fuel stations.

\section{$\mathrm{H}_{2}$ : Sales Volume $=f$ [Size of the Fuel Station (number of pumping bays)]}

A fuel retail station can only refuel as many vehicles as the number of pumping bays it has. The greater the number of pumping bays, the more motorists that can refuel without restricting the traffic flow. Motorists avoid fuel stations where there is a back up of traffic as congestion and delays occur (Smalley, 1999). Therefore, the number of pumping bays at a retail fuel station (the independent variable) was hypothesised to have an effect on the sales volume (the dependent variable) of the fuel station. When obtaining data, it was found that different fuel stations have different methods of counting the number of pumps they operate. The measure used for the regression calculation was the number of pumping bays (4-22). This is usually the number of pumps multiplied by 2 , provided sufficient nozzles are available. The dependent variable, namely, sales volume, used the average monthly sales volume in liters. Univariate regression analysis was then used to determine if a significant relationship existed between the number of pumping bays and the average monthly sales volume in liters for the surveyed fuel stations.

\section{$H_{3}:$ Sales Volume $=f($ Fuel Retail Price)}

Univariate regression analysis was used to determine if a relationship existed between the percentage change in the average annual fuel price for petrol and diesel (independent variable) and the percentage change in annual sales volume (dependent variable). Although only ten 
observations are used to construct the regression equation, each of the ten observations includes the aggregated change in price and volume of 4500-5000 fuel stations (SAPIA). Quarterly and annual sales volume data for both petrol and diesel was obtained from the SAPIA website and represent total quarterly and annual sales of their members (Mbendi, 2005h). SAPIA was formed in July 1994 and the membership currently comprises BP Southern Africa (Pty) Ltd, Chevron South Africa (Pty) Ltd, Engen Petroleum Ltd, Shell South Africa (Pty) Ltd, Total South Africa (Pty) Ltd, PetroSA (Pty) Ltd, Tepco Petroleum Ltd, and Sasol. These petroleum refining and marketing companies supply all of South Africa's 4500-5000 petrol stations with petrol and diesel.

The price data for both petrol and diesel was obtained from the Mbendi website and contains monthly nominal prices for both petrol and diesel for the past 10 years (Mbendi, 2005g). An average of the monthly prices for the respective period was used. Elasticity analysis is usually based on real, inflation adjusted prices, as opposed to nominal or current prices (TDM Encyclopedia, 2005a). However, due to the volatile nature of the South African inflation rate, and the unavailability of real fuel prices, nominal fuel prices have been used. In order to further assess and illustrate the price elasticity of petrol and diesel, a scatter gram from 1995 to 2005 was constructed to illustrate the relationship between annual petrol retail prices and diesel wholesale prices and the annual sales volume of both these fuels.

\section{The Second Research Question}

The second research question investigated whether factors other than location, fuel price and size have an affect on the profitability of fuel retail service stations. In order to test the second research question, a longitudinal case study methodology was adopted. The reason for using a case study approach was due to the qualitative nature of the data, as well as to enable the study to explore a wider range of variables that influence the profitability of the fuel retail sector (Leedy, 1993:43; Yin, 1994:64 and Leedy \& Ormrod, 2001:19). The longitudinal case study involved interviews with the owners of a selection of 15 fuel stations in the Gauteng area.

\section{THE RESULTS}

\section{The First Research Question}

The results of testing the three primary hypotheses are outlined in this section. The variables tested for 2005 (2004 in parenthesis) included sales volume (dependent variable), and the following independent variables, namely, location, size and the fuel price. The Sales volume in liters ranged between $100000(95000)$ and 600000 (700 000) with a mean value of $333476(312047)$ and a standard deviation of 21942 (22683). On the other hand, the location rating (1-10) had a mean value of 7.37 (7.26) and a minimum value of 4.5 (4.5) and a maximum of 9 (9) with a standard deviation of 0.24 (0.24). Finally, size ranged between 5 (5) cars filled simultaneously and 13 (16) with a mean value of 10.81 (10.6) and a standard deviation of $0.605(0.59)$.

\section{$\mathrm{H}_{1}$ : Sales Volume $=f$ (Location)}

A scattergram, illustrated in Figure 2, illustrates the relationship between sales volume and location for 2005. 
Figure 2: Sales volume versus location

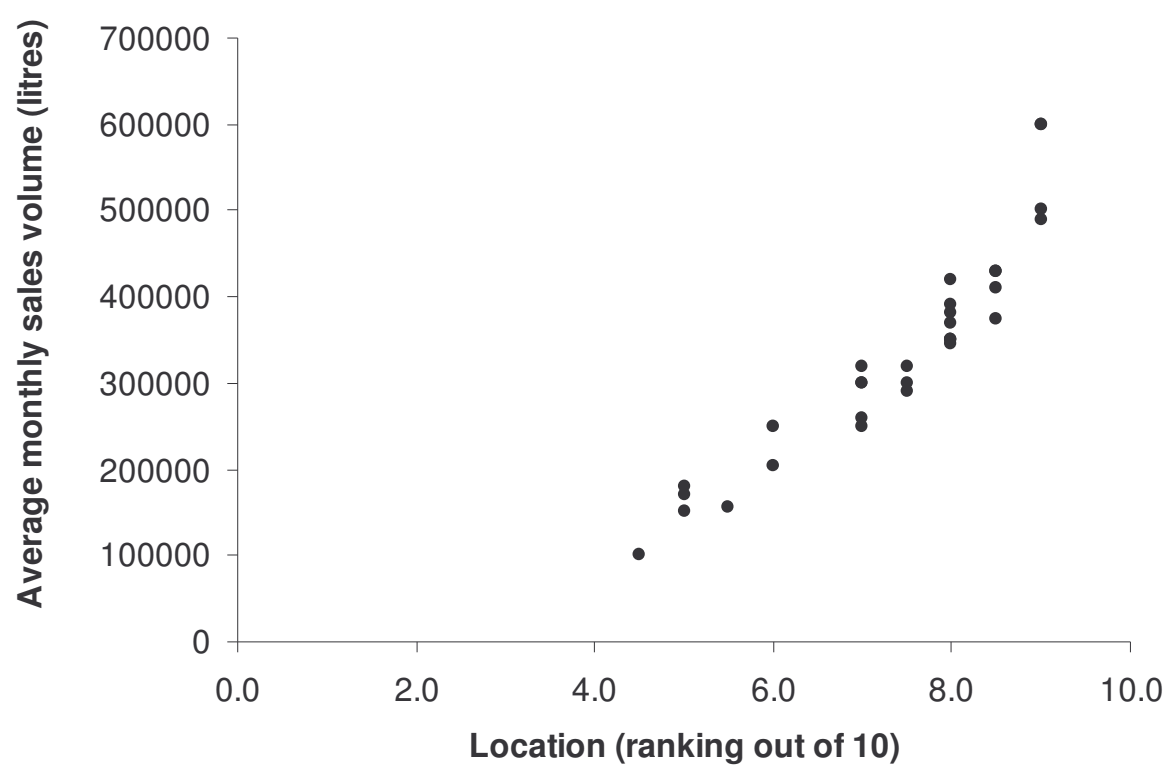

The plotted points appear to be closely grouped about the line of best fit indicating a high level of correlation between sales volume and location. A univariate regression model was then developed for 2004 and 2005 with 31 and 29 observations respectively. A coefficient of determination $\left(R^{2}\right)$ for the raw data of 0.86 for 2005 ( 0.76 for 2004) indicates a high goodness of fit. Furthermore, the $t$ values of the independent variable were highly significant (13.59 and 9.34 for 2005 and 2004) further supporting the assumption that location has a significant influence on monthly sales volume. An analysis of the residuals, however, using the Cooks Distance Test $(4 / n)$, suggested that two observations were both outliers, as well as unduly influential. Furthermore, the results suggested that the model did not comply with the conditions of normality, homoscedascity or linearity. In order to construct a more robust model, the two unduly influential observations were removed because they represented two fuel stations on national highways whilst all the others were constrained to urban locations in Gauteng. Furthermore, an analysis of the independent variables indicated that a transformation of location, namely, location cubed, would maximise the revised model's predictive abilities, as well as the level of significance of the independent variable.

Table 1: Regression 2005: sales volume versus location ${ }^{3}$ (2004 in parenthesis)

\begin{tabular}{|c|c|c|c|c|c|}
\hline \multicolumn{3}{|c|}{ Regression Statistics } & & & \\
\hline $\begin{array}{l}\text { Observations } \\
\text { Adjusted R Square } \\
\text { F-Stat } \\
\text { P Value (F-Stat) }\end{array}$ & $\begin{array}{l}29 \\
0.94 \\
425.56 \\
<0.001\end{array}$ & $\begin{array}{c}(29) \\
(0.67) \\
(58.08) \\
(<0.000)\end{array}$ & & & \\
\hline X1 Location $^{3}$ & $\begin{array}{l}\text { Coe } \\
539 \\
(56\end{array}$ & $\begin{array}{l}\text { ients } \\
73 \\
6)\end{array}$ & $\begin{array}{l}\text { Standard Error } \\
26.16 \\
(74.59)\end{array}$ & $\begin{array}{c}T \text { Stat } \\
20.63 \\
(7.62)\end{array}$ & $\begin{array}{c}\text { P-Value } \\
0.000 \\
(0.000)\end{array}$ \\
\hline
\end{tabular}

There was a significant positive correlation between total sales and location cubed. The coefficient for location cubed was 539.67, indicating that a change of 1 in this score is associated with an average change of sales volume of 54912 liters per month. The adjusted $R^{2}$ is 0.94 , indicating that the model explains $94 \%$ of the variance from the mean. The F-statistic of 425.56 is also highly significant. The Shapiro-Wilk test indicates a 0.75 probability that the residuals are normally distributed whilst the Cook-Weisburg test for heteroscedascity indicates a 0.57 probability that there is a constant variance. Finally, the transformed model has been tested for linearity and the Ramsey 
RESET test indicates that the model specification does not have an omitted variable. Given the significance of these results, the first hypothesis $\left(\mathrm{H}_{1}\right)$ is accepted and the null hypothesis rejected for both petrol and diesel.

\section{$\mathrm{H}_{2}$ : Sales Volume $=f$ [Size of the Fuel Station (number of pumping bays)]}

A scattergram, illustrated in Figure 3, shows the average monthly sales volume versus the number of pumping bays for 2005.

Figure 3: Size versus average monthly sales

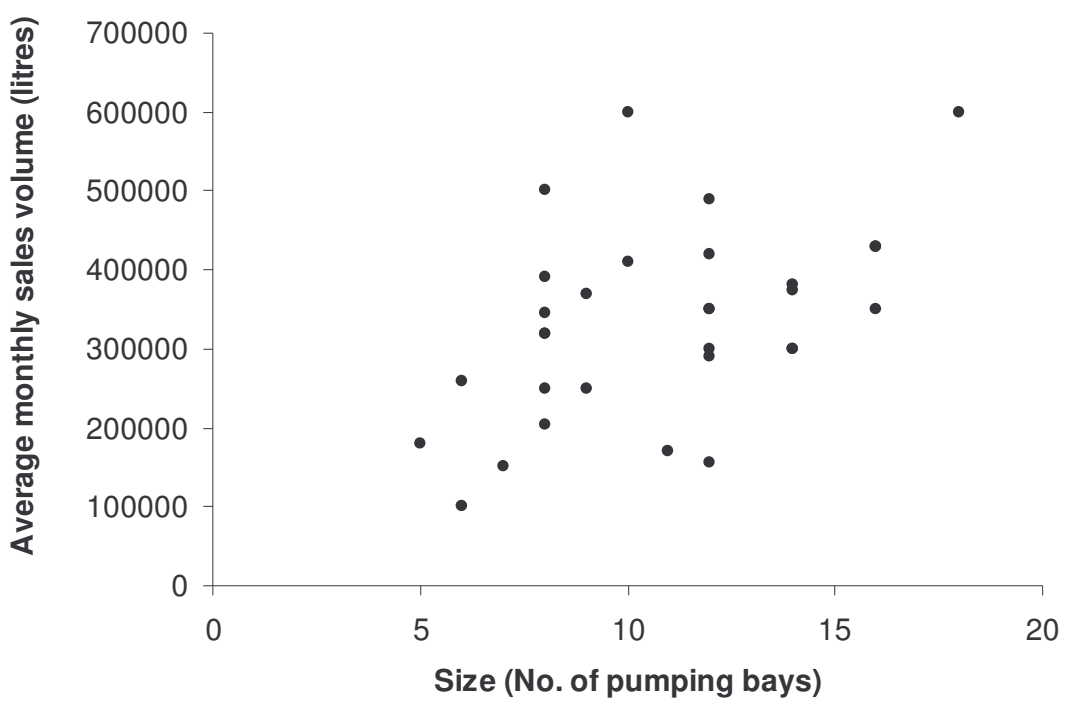

Although the general slope of the scattergram is positive, the plotted points are widely dispersed around a hypothetical line of best fit. The scattergram, therefore, suggests a tentative level of correlation between sales volume and the number of pumping bays.

Table 2: Regression 2005 (2004 in parenthesis): sales versus size

\begin{tabular}{|c|c|c|c|c|c|}
\hline \multicolumn{6}{|c|}{ Regression Statistics } \\
\hline $\begin{array}{l}\text { Observations } \\
\text { Adjusted R Square } \\
\text { F-Stat } \\
\text { P Value (F-Stat) }\end{array}$ & $\begin{array}{l}31 \\
0.21 \\
8.80 \\
0.006\end{array}$ & $\begin{array}{c}(29) \\
(0.18) \\
(7.25) \\
(0.012)\end{array}$ & & & \\
\hline \multicolumn{3}{|c|}{ Coefficients } & Standard Error & $T$ Stat & $P$-Value \\
\hline X2-Size & \multicolumn{2}{|c|}{$\begin{array}{c}17490.41 \\
(17553.48)\end{array}$} & $\begin{array}{c}5894.97 \\
(6519.20)\end{array}$ & $\begin{array}{l}2.97 \\
(2.69)\end{array}$ & $\begin{array}{c}0.006 \\
(0.012)\end{array}$ \\
\hline
\end{tabular}

There is a low level of positive correlation between sales volume and size. The coefficient for size was 17490, indicating that an increase of one pump is associated with an increase in monthly sales volume of 17490 liters. The adjusted $R^{2}$ for the model is $0.21(0.18)$, indicating that the model only explains between $18 \%$ and $21 \%$ of the variance from the mean for 2005 and 2004 respectively. The F-statistic of 8.80, however, is significant. A multivariate model for 2005 (2004) was then developed to further evaluate the significance of fuel station size. 
Table 3: Multiple regression 2005 (2004 in parenthesis): sales versus location and size

\begin{tabular}{|c|c|c|c|c|c|}
\hline \multicolumn{6}{|l|}{ Regression Statistics } \\
\hline $\begin{array}{l}\text { Observations } \\
\text { Adjusted R Square } \\
\text { F-Stat } \\
\text { P Value (F-Stat) }\end{array}$ & $\begin{array}{l}31 \\
0.85 \\
89.16 \\
0.000\end{array}$ & $\begin{array}{c}(29) \\
(0.76) \\
(42.20) \\
(0.000)\end{array}$ & & & \\
\hline $\begin{array}{l}\text { X1 Location } \\
\text { X2 Size }\end{array}$ & & $\begin{array}{l}\text { icients } \\
12.4 \\
525.7) \\
5.92 \\
92.51)\end{array}$ & $\begin{array}{c}\text { Standard Error } \\
7544.7 \\
(10436.3) \\
2946.4 \\
(4191.98)\end{array}$ & $\begin{array}{l}\text { T Stat } \\
11.41 \\
(7.81) \\
0.04 \\
(0.28)\end{array}$ & $\begin{array}{c}\text { P-Value } \\
0.0000 \\
(0.0000) \\
0.966 \\
(0.7788)\end{array}$ \\
\hline
\end{tabular}

When location and size are included in the multivariate model, size is no longer significant (Stata Version 9). The results suggest a high level of probability (P-Value $=96.6 \%$ and $77.8 \%$ ) that size does not influence sales volume for 2005 (2004) with T-Stats of 0.04 and 0.28 respectively.

On the basis of the scattergram, the low level of fit of the univariate 2005 and 2004 results, as well as its rejection in the multivariate model, the second hypothesis $\left(\mathrm{H}_{2}\right)$ is rejected and the null hypothesis is accepted.

\section{$\mathrm{H}_{3}$ : Sales Volume $=f$ (Fuel Retail Price)}

\section{Petrol}

In order to calculate the price elasticity of demand for petrol, the percentage change in total annual sales volumes from the SAPIA group members (4500-5000) for the last 10 years was regressed against the percentage change in the petrol retail price for that period. The following results were indicated:

\section{Table 4: Petrol regression analysis}

\begin{tabular}{|c|c|c|c|c|}
\hline \multicolumn{5}{|l|}{ Regression Statistics } \\
\hline $\begin{array}{l}\text { Observations } \\
\text { Adjusted R Square } \\
\text { F-Stat } \\
\text { P Value (F-Stat) }\end{array}$ & $\begin{array}{l}11 \\
0.48 \\
10.14\end{array}$ & & & \\
\hline $\begin{array}{l}\text { Intercept } \\
\text { X Variable- Fuel Price }\end{array}$ & $\begin{array}{c}\text { Coefficients } \\
0.0381 \\
-0.2408\end{array}$ & $\begin{array}{c}\text { Standard Error } \\
0.0098 \\
0.0756\end{array}$ & $\begin{array}{r}T \text { Stat } \\
3.8935 \\
-3.1844 \\
\end{array}$ & $\begin{array}{l}P \text {-Value } \\
0.0038 \\
0.0111\end{array}$ \\
\hline
\end{tabular}

An adjusted $R^{2}$ of 0.48 indicates a reasonable goodness of fit indicating that over time an increase in price explains $48 \%$ of changes in sales volumes. The $t$-value of the independent variable of -3.18 is significant, further supporting the assumption that a positive percentage change in the petrol price influences a negative change in the volume of petrol sold over time. These tests suggest that, as the petrol price increases, the volume of petrol sold decreases over time.

Because of the limited observations in the regression calculation (11), a graph for the period 1995 to 2005 , illustrated in Figure 4, was constructed to represent the relationship between fuel price and volume. 
Figure 4: Percentage change in price and volume versus time

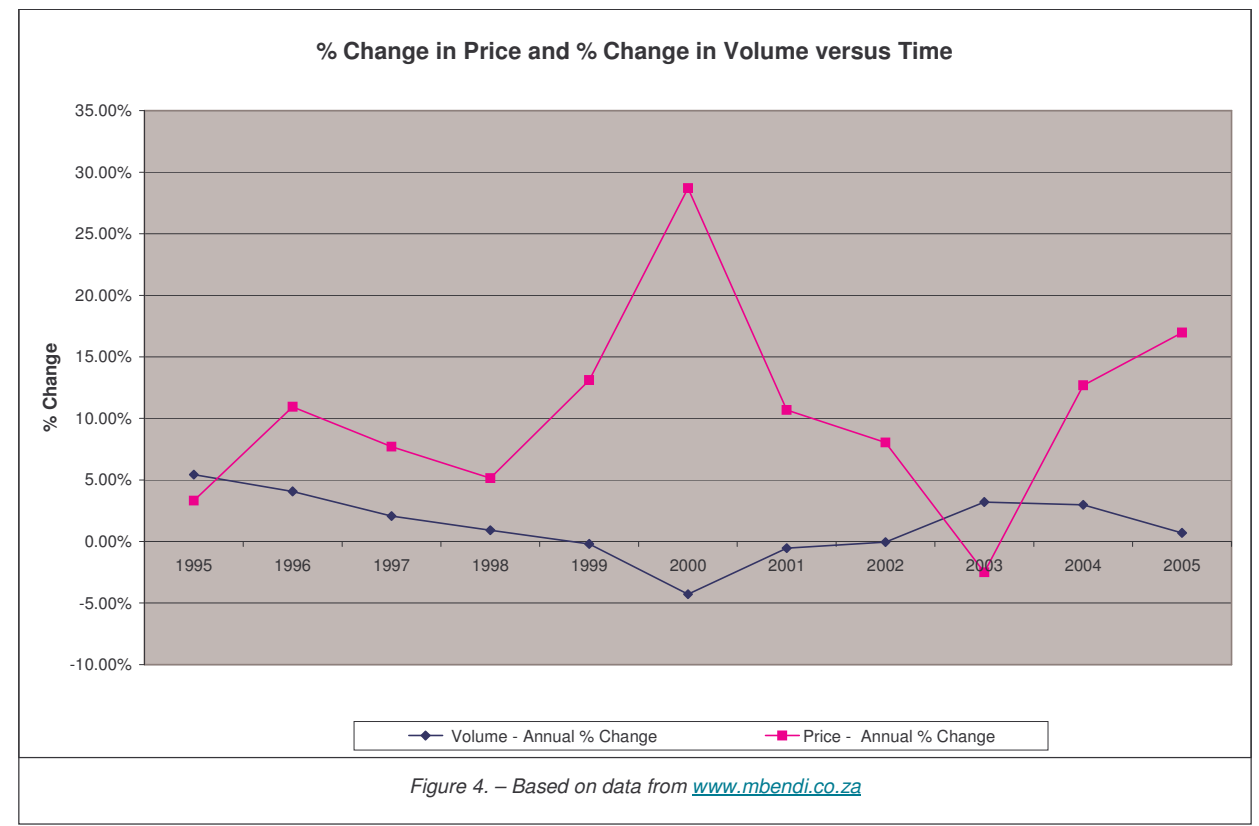

Despite some contradictions, the graph indicates that over the long term the two variables show some degree of negative correlation. For example in 1996, 1999, 2000, 2001, 2002, 2003, 2004 and 2005 sales volume is negatively correlated with the retail price. In the short term, however, the graph indicates the inelastic nature of the petrol price. This is specifically evident for the year 2000 where a $29 \%$ increase in the petrol price resulted in only a $4 \%$ decrease in the volume sold, indicating that change in volume is fairly insensitive to change in price. Given the significance of the regression results, as well as the visual evidence of the graph, the third hypothesis $\left(\mathrm{H}_{3}\right)$ is accepted if change in price and volume is measured over the long term.

\section{Diesel}

In order to test the price elasticity of demand for diesel, the percentage change in total annual sales volumes from the SAPIA group members for the last 10 years was also regressed against the percentage change in the diesel wholesale price. Regression analysis conducted between the percentage change in price and the percentage change in volume for diesel yielded the following results:

\section{Table 5: Diesel regression analysis}

\begin{tabular}{|lc|ccc|}
\hline Regression Statistics & & & \\
Observations & 11 & & & \\
Adjusted R Square & -0.11 & & & \\
F-Stat & 0.0024 & & & \\
P Value (F-Stat) & & & & \\
& & & & \\
& & & \\
& Coefficients & Standard Error & T Stat & P-Value \\
Intercept & 0.0411 & 0.0092 & 4.4390 & 0.0016 \\
X Variable- Fuel Price & 0.0028 & 0.0575 & 0.0495 & 0.9615 \\
\hline
\end{tabular}

A coefficient of determination $\left(R^{2}\right)$ of 0.0003 indicates changes in the price of diesel do not result in changes in sales volume. In support of this contention, the $t$-value of the independent variable is very low indicating an insignificant relationship between the dependent and independent variables. A value near zero means that there is a random or nonlinear relationship between the two variables. The price elasticity of demand calculated for diesel was -0.003 , indicating that diesel is almost fully 
inelastic and that change in volume is virtually insensitive to change in price. Therefore, the percentage change in diesel sales volume is not a function of the percentage change in diesel wholesale price, and the third null-hypothesis is accepted with respect to diesel.

\section{The Second Research Question}

The second research question employed a case study methodology to test whether factors other than location, fuel price and size influenced the profitability of fuel retail service stations. The results suggest the following key variables also influence profit. They are:

- Convenience Stores - interviewees felt that this was essential to attracting customers. Many customers stopped at the fuel retail station just to purchase items from the convenience store. The presence of a convenience store attracted more customers to refuel, while purchasing high margin products from the convenience store at the same time. This helped to differentiate fuel retail stations and increased profitability. A number of interviewees, moreover, indicated that their fuel retail stations were only profitable due to the presence of the convenience store. The important influence of convenience stores on the profitability of retail fuel stations is well illustrated in the literature (Netz \& Taylor, 2002; Bainbridge, 2000 and Weirauch, 2000).

- All fuel station owners or managers interviewed felt that service was a crucial aspect. One fuel station owner said, "A customer can have 10 good occasions followed by one bad occasion and that one bad occasion will result in the customer not coming back." Interviewees also felt that well trained and friendly staff added to good service and thus encouraged customers to return to the fuel station. These results are supported by another survey conducted on $74 \mathrm{BP}$ sites around South Africa that indicated that an average $97.4 \%$ of people felt they spent an acceptable amount of time waiting for their fuel transaction to be completed, with only $2.6 \%$ of people feeling they waited a little too long (Peacock Consulting, 2004).

- Interviewees also felt that loyalty contributed an important part to reaching the monthly sales volume. The importance of loyalty is illustrated by another survey of 74 BP sites around South Africa, that indicated that an average $31 \%$ of fuel station users were very loyal in that of the last 5 times they used a fuel station, they used one particular station and $17.5 \%$ of fuel station users were loyal in that 4 out of the last 5 times they used a fuel station, they used one particular station. In contrast, $33.5 \%$ of fuel station users were classified as first time users of the fuel station (Peacock Consulting, 2004).

- Diesel price - interviewees felt that people would shop elsewhere for cheaper diesel. The fact that people will shop elsewhere for cheaper diesel is also an indicator that deregulation will encourage competition between fuel stations.

- Rental - of the fuel stations included in the case study, the managers of those that paid rent felt that the rental expenses were excessively high, sighting that as a direct cause of the loss situation experienced by those fuel stations.

- Supply - interviewees felt that fuel shortages experienced by the fuel stations due to supplier problems affected both current sales, as there was no stock to sell, and future sales due to customers' loyalty diminution.

- Appearance - interviewees felt that a poor appearance of the fuel station resulted in a low number of customers and therefore low sales. A neat shop and good maintenance and signage were identified as key appearance aspects. A spacious and well set-out fuel station was, therefore, a key aspect that attracted customers.

- Good management, information technology, and controls to limit losses were also identified as key aspects to ensure a profitable fuel station.

- Competition - due to the legislative price controls, fuel stations cannot compete at price level. Therefore, other competitive techniques were adopted such as new and better marketing, good 
service and superior product. Development in the vicinity of existing fuel stations brings both more customers and new competitors. New fuel stations directly affect sales volumes.

- Brand name - some interviewees felt that sales volumes were driven to a certain extent by loyalty to the brand name.

- Security - some interviewees felt that security and safety played an important role in the number of customers that the fuel station attracts, directly affecting sales volume.

- Efficient marketing, advertising, promotions and specials combined with convenience stores were other features identified by interviewees as elements that attract customers to the fuel station.

In response to the second research question, therefore, these results suggest that a wide range of factors other than location, fuel price and the size of the fuel station influence the sales volume of a fuel station.

\section{DISCUSSION AND RECOMMENDATIONS}

The study largely supports some of the conclusions of the SBAB (2004) study, as well as those of the Bureau of Economic research. However, the study makes a contribution by better quantifying these relationships by the use of quantitative, graphical and case study techniques. The results indicated the acceptance of the first hypothesis underlying the significance of location on sales volume. This has also been confirmed by a number of studies in other countries that suggest location is a key variable influencing the profitability of service stations. In particular, these studies suggest the development of location criteria for rural service stations (Scottish Executive Publications, 2006; Siam Future Development PLC, 2006 and National Statistics, 2006). Furthermore, the relationship between sales volume and location is economically plausible based on the fact that it is logical to assume that location influences sales volume because of the volume of passing traffic, access and proximity to a major route. Finally, the importance of the choice of province may be significant in a South African context with Gauteng being the leading consumer of petrol and diesel (Mbendi, 2005e).

Quite surprisingly, the importance of the relationship between the number of fuel pumping bays and sales volume was not significant when compared to location. This suggests that extra pumps do not necessarily equate to extra sales volume and probably inflate the fuel storage costs and overheads of the relevant outlet. This questionable level of correlation is contradicted by the economic plausibility of the relationship between the variables that suggests that a fuel station can only fill as many cars as the number of pumping bays it has. It is recommended that prospective owners, therefore, carefully survey the likely fuel consumption on the basis of location and then choose the minimum number of pumping bays to service this capacity with an option to increase the number of pumping bays in the event of sustained additional volumes. In addition, station owners could monitor the fuel sales per pump as a way to manage the efficiency of the attendants.

The price elasticity of demand for petrol appeared to concur with international estimates that range between -0.10 in the short term and -0.8 in the long term (Bailly, 1999; Graham \& Glaister, 2002 and Bureau of Economic Research, 2003). In particular, the regression results suggest a fairly strong negative relationship in the long term that is supported by the graphical evidence of sales volumes and retail price between 1995 and 2005 in South Africa. The higher levels of short term petrol price inelasticity are supported by evidence in the period 2003-2004 where a sharp increase in petrol price was accompanied by an unchanged demand for fuel. This is consistent with the short-term price elasticity of demand results obtained for both South African and international fuel products. The percentage change in volume has not exceeded $5 \%$ in the last 10 years, again indicating the short term inelastic nature of petrol. In support of short term inelasticity, research conducted by Nielsen (2004) with regards to people's reaction to petrol price increases found that, of the 2474 people interviewed, $53 \%$ did not know what the actual petrol retail price was. The conclusion made by the report is that "changes in the petrol price have become part of the 'economic background noise' for most people," and therefore concludes that petrol is a relatively inelastic product (Nielsen, 2004). In conclusion, however, it is recommended that petrol station 
owners attempt to follow long range forecasts of the oil price and use this to adjust long term sales volume predictions.

The inelastic nature of diesel consumption appears to be very high suggesting that South African industry is totally reliant on road transport. The price elasticity of demand for diesel calculated above was -0.003 , indicating that diesel is almost fully inelastic. A low price elasticity of demand for diesel is consistent with results obtained by the Bureau of Economic Research for the price elasticity of demand for diesel in South Africa. Le Roux (2002) sites the fact that diesel has "fewer optional uses and is more business-orientated than petrol" as the main reason for its inelastic nature. However, it has been hypothesised that, as diesel-powered passenger car sales rise, more optional diesel users will be created that may contribute to higher levels of diesel price elasticity (Le Roux, 2002).

The case study identified other factors that affect the profitability of fuel retail service stations. These factors included convenience stores, loyalty, service, rental and appearance. Other factors included good management, competition, staff, security, efficient marketing and additional services. In this regard, these additional factors are supported by other international studies (Nault \& Dexter, 2003). The most popular additional source of income is the convenience store. In many situations, convenience stores appeared to fully supplement losses made by forecourt activities resulting in an overall net profit for the fuel station. In a survey conducted by Peacock Consulting on 74 BP sites around South Africa, $66 \%$ of people visiting the fuel station did so with the main purpose of buying from the convenience store. In comparison, only 34\% visited the service station to purchase fuel (Peacock Consulting, 2004) with the average spent at the convenience store being R 20.50, and $15.3 \%$ of convenience store customers spending over R30.00. Other additional services include banking and ATM's, car-wash, fast food outlets, motor car sales, lotto outlets, public telephones and cellular telephone supplies (Human Sciences Research Council, 1992).

The following additional data produced by the case study is relevant:

- Of the 15 fuel stations included in the case study, all 15 of the fuel stations produced a net profit when considering all activities;

- 6 of the fuel stations were not profitable when considering only forecourt activities;

- All of the fuel stations that sold more than 370000 liters of fuel per month were profitable when considering only forecourt activities;

- 2 out of the 15 fuel stations included in the case study were owned by supplier-oil companies and franchised to dealers. Both of these fuel stations were not profitable when considering only forecourt activities, sighting excessively high rentals and franchise fees as the cause.

Other ways to increase returns to fuel station owners should also be considered. If supplier-oil companies supplied fuel stations on a consignment basis for stock, as opposed to demanding upfront payment, this would relieve interest charges on financing stock. Fuel station owners would also not be subject to the risk due to price fluctuations. Another aspect where supplier-oil companies could relieve the financial burden of fuel station owners would be to reduce the excessively high rentals they demand for their sites (FleetCube, 2005).

\section{The Impact of Deregulation}

The Minister of Minerals and Energy recently reported that, due to the changes in the Petroleum Products Act, South Africa was well on its way to deregulation (Mbendi, 2004b), however, there are indications that deregulation might not happen for some time (Sunday Times, 2005a). The deregulation of the South African fuel industry is expected to cause a variety of changes to the sector. Deregulation will result in the supplier-oil companies being able to charge whatever price they choose. Fuel retailers will be able to "shop around" to find the cheapest supplier. This would encourage greater competition in the sector. Import and export controls would be phased out, allowing companies to import and refine crude oil. This would also allow companies to import the finished product (Mbendi, 2005d). 
Deregulation is likely to have extensive effects on the overtraded fuel retail market. Lower pump prices caused by additional competition will result in lower profit margins being received by fuel stations (Africa News Service, 2004 and Visser, 2005). The Human Sciences Research Council foresees deregulation having extensive consequences for existing fuel stations, with the likely demise of marginal outlets and the reduction in the number of low volume rural outlets. The Financial Mail predicts that approximately 1600 of the current 4800 fuel stations could close once the market is liberalised (Pile, 2005:47). A side effect of the termination of these fuel stations is the major job losses that would result (Mbendi, 2004b; 2005c). Furthermore, the potential competition caused by deregulation could destroy the current black economic empowerment progress in the sector. Therefore, black empowerment groups have requested that deregulation be postponed until they hold between $20 \%$ and $25 \%$ of the market share. Currently, black-owned oil companies hold under $4 \%$ of the market share. The positive side of deregulation, however, is in the fact that it removes monopolistic conditions. Deregulation would result in a more competitive environment by allowing more players into the market as well as introducing a free pricing system. Overall, the DME feel that the general public is paying higher prices in order to subsidise discounted customers or other customers with "special deals" (The Department of Minerals and Energy, 2004). This should encourage more competitive prices among dealers, resulting in lower prices for the benefit of the consumer (Nnabuike, 2004).

Before deregulation can occur in the South African fuel industry, certain milestones need to be reached. The Financial Mail reported that deregulation is unlikely to occur until the new pipeline between Durban and Gauteng is completed. This pipeline will aid in the transportation of fuel from the coast to supply the large inland demand, with completion planned for 2010 (Pile, 2005:47).

\section{SUMMARY AND CONCLUSION}

The objective of this article was to examine the factors that influence the profitability of individual fuel stations. The first research question examined three predictor variables that could have an effect on the profitability of fuel retail service stations, namely, location, size and the petrol price. The location of the fuel station was found to be positively related to profit. The usefulness of the results is that certain locations do not have potential and future long term planning of the industry needs to make alternative arrangements to rationalise the fuel stations in marginal areas. In this regard, the study makes a contribution by better quantifying these relationships in the form of a reliable univariate regression model to forecast sales. With regards to the importance of location, however, the conclusions are limited to urban areas in Gauteng and do not apply to fuel stations in rural areas or on national highways. The results also suggest that fuel station size is a less critical variable but proposes that managing the pump to cost ratio is a critical variable and that extra pumps cost money if they are not fully utilised. The petrol and diesel retail price elasticity suggested slightly divergent scenarios. In the case of petrol, short term inelasticity is countered by longer term elasticity and it appears that if the retail price increases substantially over time, there will be a drop in demand. Conversely, no effect on sales volume appeared likely in the case of diesel sales. The usefulness of these results could be included in the long term planning of fuel consumption patterns in South Africa in the face of increased oil prices and alternative forms of transport.

In order to determine other key variables that influence the profitability of individual fuel stations, a second research question examined whether variables other than location, fuel price and the size of fuel station have an affect on the profitability of fuel retail service stations. In this regard, the interviewees supported the literature that other factors could significantly influence the profitability of service stations. These factors included convenience stores, service, the diesel price, additional services offered, and competition. Furthermore, the results suggested that eight out of the fifteen respondents indicated that the additional services were the only reason for their service station reflecting a profit.

In conclusion, the impact of deregulation was assessed. In this regard, it was proposed that deregulation could have a significant affect on the economics of the retail fuel sector, allowing supplier-oil companies to compete amongst themselves and fuel retailers to set prices that will ensure they produce a positive return. At this point, deregulation is not likely to result in the total elimination of government involvement in the sector with the government still involved in setting the maximum pump price, rates of duties and taxes, and the minimum product standards (Mbendi, 
2005d). Finally, other areas of research identified by this report could include the examination of further variables that influence the profitability of fuel retail service stations. In particular, the impact of new vehicle sales as a result of a rapidly expanding urban middleclass should be investigated with respect to their influence on fuel price elasticity. Finally, a detailed examination into the price elasticity of demand for fuel should be further investigated in relation to the proposed deregulation plans in this sector.

\section{REFERENCES}

Africa News Service. 2004. Deregulation and Fuel Crisis: the Dialogue Option [Online] Available from: /0-web7.infotrac.galegroup.com.innopac.wits.ac.za [Accessed: 11/08/2005].

Bailly H. 1999. Potential for Fuel Taxes to Reduce Greenhouse Gas Emissions from Transport Transportation Table of the Canadian National Climate Change Process. Cited in TDM Encyclopedia. Fuel Taxes: Increasing Fuel Taxes and Fees [Online] Available from: www.vtpi.org/tdm/tdm17.htm [Accessed: 11/08/2005].

Bain J. 2005. Fact Box.Sunday Times. [Online] Available from: www.sundaytimes.co.za/Articles/TarkArticle.aspx?ID=1741213 Accessed: 16/11/2005].

Bainbridge R. 2000. Analyzing the market for convenience stores: The changing convenience store industry. Appraisal Journal 68(4):427.

Begg D. 2000. Economics. $6^{\text {th }}$ ed. England: McGraw-Hill.

Blum U, Foos G \& Guadry M. 1988. Aggregate time series gasoline demand models: review of the literature and new evidence for West Germany. Transportation Research, 22A:75-88

Bureau for Economic Research. 2003. [Online] Available from: www.ber.sun.ac.za/downloads/2004/fueltax/fuel_present.pdf [Accessed: 22/01/2006].

Chan T, Padmanabhan V \& Seetharaman P. 2005. Modelling locations and pricing decisions in the gasoline market: A structural approach [Online] Available from: http://www.olin.wustl.edu/workingpapers/pdf/2005-08-018.pdf [Accessed: 27/10/2006].

Cohen M. 2005. Petronas's Engen unit leads pack in fuel sales [Online] Available from: www.businessreport.co.za/ index.php?fArticleld=2531221 [Accessed: 30/08/2005].

Espey M. 1996. Explaining the variation in elasticity estimates of gasoline demand in the United states: a meta analysis. The Energy Journal, 17(3):22-49.

FleetCUBE. 2005. [Online] Available from: www.fleetcube.com $/ \mathrm{html} / \mathrm{dsfuelmanag.html}$ [Accessed: 15/08/2005].

Graham D \& Glaister S. 2002. The Demand for Automobile Fuel: A Survey of Elasticities. Journal of Transport Economics and Policy, 36:1-26.

Harwood J. 2006. Life beyond petrol. Marketing Week, 24

Hillingdon Times. 2006. News Analysis: Forecourt fortunes [Online] Available from: http://hillingdontimes.co.uk [Accessed: 15/02/2006].

Human Sciences Research Council. 1992. In Terror and in Silence [Online] Available from: www.hsrcpress.ac.za/user_uploads/tblPDF/ [Accessed: 17/06/2005].

Leedy PD. 1993. Practical Research: Planning and Design. $5^{\text {th }}$ ed. New York: Macmillan Publishing Company. 
Leedy PD \& Ormrod JE. 2001 Practical research: Planning and design. $7^{\text {th }}$ ed. Upper Saddle River, NJ: Merrill.

Lee Y \& Schmidt C. 1980. A comparative location analysis of retail activity: The gasoline service station. The Annals of Regional Science, 14(2):55-65.

Le Roux H. 2002. Diesel production is set to rise [Online] Available from: www.engineeringnews.co.za/eng/features/oilrefiner/?show=26838 [Accessed: 22/01/2006].

MBENDI, Information for Africa. 2004a. SAPIA, South African Petroleum Industry Association [Online] Available from: www.mbendi.co.za/sapia/ pubs/2004_ARep/p06.htm [Accessed: 03/12/2005].

MBENDI, Information for Africa. 2004b. SAPIA, South African Petroleum Industry Association. 2004 Annual Report [Online] Available from:

www.mbendi.co.za/sapia/pubs/2004_ARep/SAPIA_Appendices_2004.pdf [Accessed: 1012/2005].

MBENDI, Information for Africa.2005a. South Africa: Oil and Gas Overview [Online] Available from: www.mbendi.co.za/ indy/oilg/af/sa/p0005.htm [Accessed: 02/07/2005].

MBENDI, Information for Africa.2005b. South Africa: Oil and Gas Summary [Online] Available from: www.mbendi.co.za/ indy/oilg/af/sa/p0020.htm\#top [Accessed: 02/07/2005].

MBENDI, Information for Africa.2005c. South Africa: Oil and Gas Key Issues [Online] Available from: www.mbendi.co.za/ indy/oilg/af/sa/p0015.htm [Accessed: 02/07/2005].

MBENDI, Information for Africa.2005d. South Africa: Oil and Gas White Paper [Online] Available from: www.mbendi.co.za/ indy/oilg/af/sa/p0025.htm [Accessed: 02/07/2005].

MBENDI, Information for Africa. 2005e. SAPIA, South African Petroleum Industry Association [Online] Available from: www.mbendi.co.za/sapia/pdf/2005_Q1pr.xls [Accessed: 30/08/2005].

MBENDI, Information for Africa. 2005f. SAPIA, South African Petroleum Industry Association. Growth in petroleum product sales falters in third quarter of 2005 (SAPIA News - Item [71365]: News Release [Online] Available from:

www.mbendi.co.za/a_sndmsg/news_view.asp?l=71365\&PG=25 [Accessed: 16/11/2005].

MBENDI, Information for Africa. 2005g. South African Petrol Industry Association [Online] Available from: www.mbendi .co.za/indy/oilg/ogds/af/sa/p0020.htm [Accessed: 16/11/2005].

MBENDI, Information for Africa. 2005h. SAPIA, South African Petroleum Industry Association [Online] Available from: www.mbendi.co.za/sapia/rsacons.htm [Accessed: 16/11/2005].

National Statistics 2006. UK Snapshot [Online] Available from: www.statitistics.gov.uk [Accessed: 15/02/2006].

Nault BR \& Dexter AS. 2003. Added Value and Pricing with Information Technology. MIS Quarterly, 19(4):449-461.

Netz J \& Taylor B. 2002. Maximum or minimum differentiation? Location patterns of retail outlets. Review of Economics and Statistics, 84(1):162-182.

Nielsen AC. 2004. Many South Africans unaware of petrol price impacts [Online] Available from: biz-community.com/Article/196/19/4580.html [Accessed: 22/01/2006].

Nnabuike C. 2004. Asia Africa Intelligence Wire. Deregulation And Fuel Pricing [Online] Available from: $<$ http://0-web7.infotrac.galegroup.com.innopac.wits.ac.za/ itw/infomark/575/77/66289493w7/purl=rc1_GBFM_0_A119501664\&dyn=7!xrn_5_0_A119501664?sw_ae p=uow_itw [Accessed: 11/08/2005]. 
Peacock Consulting. 2004. A Survey of BP Retail Fuel Stations. Site Profiling Report.

Pile J. 2005. Mutters About Monopoly. Financial Mail, 181(10):47.

Reid K. 2004. Leveraging Convenience, National Petroleum News, October:22.

SBAB (Potchefstroom University Small Business Advisory Bureau). 2004. Retail Margin Investigation for 2004.

Scottish Executive publications. 2005. Review of rural petrol stations grant final report [Online] Available from: www.scotland.Gov.uk [Accessed: 21/12/2006].

Shell Southern Africa. 2005. Fuel Prices [Online] Available from: http://shell.co.za/ vpower/pprice.htm [Accessed: 27/12/2005].

Siam Future Development PLC. 2005. Thailand Gas Station Industry [Online] Available from: www.siamfuture.com [Accessed: 15/02/2006].

Smalley S. 1999. Measuring convenience of gas stations. Appraisal Journal, October:339-347

South African Petroleum Industry Association. 2005. General Information [Online] Available from: www.sapia.org.za/ [Accessed: 27/10/2006].

Statistics South Africa. 2005 [Online] Available from: www.statssa.gov.za/ publications/ P0441/P04412ndQuarter2005.pdf [Accessed: 17/11/2005].

SundayTimes. 2005a. [Online] Available from: www.sundaytimes.co.za/ Articles/TarkArticle.aspx?|D=1741505 [Accessed: 16/11/2005].

SundayTimes. 2005b. Excluded Groups Want Their Share of Black Gold [Online] Available from: www.btimes.co.za/98/1115/news/news03.htm [Accessed: 02/07/2005].

TDM Encyclopedia. 2005a. Transportation Elasticities: How Prices and Other Factors Affect Travel Behavior [Online] Available from: www.vtpi.org/tdm/ tdm11.htm [Accessed: 23/11/2005].

TDM Encyclopedia.2005b. Fuel Taxes: Increasing Fuel Taxes and Fees [Online] Available from: www.vtpi.org/tdm/tdm17.htm [Accessed: 11/08/2005].

The Department of Minerals and Energy. 2004. Terms of Reference: An Investigation into the Potential Need and Impact of Regulating the Price of Diesel at the Wholesale and/or Retail Levels [Online] Available from:www.dme.gov.za/publications/pdf/tenders/task130_tor.pdf [Accessed: 23/08/2005].

The Department of Minerals and Energy. 2005a. [Online] Available from: www.dme.gov.za/ energy/petrol_structure.htm [Accessed: 23/08/2005].

The Department of Minerals and Energy. 2005b. [Online] Available from: www.dme.gov.za/ energy/petrol93gautfeb.htm [Accessed: 23/08/2005].

Thomas S. 2005. New Law May Introduce Much Needed Common Sense. Financial Mail, 181(10):46.

Visser A. 2005. Unmanaged deregulation to cause chaos. Gauteng Business,18:3.

Weirauch W. 2000. Fuel retailing is changing in Europe. Hydrocarbon processing, January: 9.

Yin R. 1994. Case Study Research: Design and Method. $2^{\text {nd }}$ ed. Beverly Hills, Ca: Sage Publishing. 